\title{
COMPUTER SCIENCE
}

\section{ДЕЯКІ ПИТАННЯ СТВОРЕННЯ КОНЦЕПТУАЛЬНОЇ МОДЕЛІ ІНФОРМАЦІЙНОӦ СИСТЕМИ УПРАВЛІННЯ ОЗДОРОВЛЕННЯМ ВІЙСЬКОВОСЛУЖБОВЦІВ}

\author{
К.б.н., Горбунов Олег, ORCID: 0000-0002-8483-3530 \\ К.т.н., Осадчий Свген, \\ Професор, д.ф-м.н., Терещенко Василь, ORCID: 0000-0002-0139-6049 \\ Украӥна, Київ, Київський національний університет імені Тараса Шевченка
}

DOI: https://doi.org/10.31435/rsglobal_ws/30112019/6765

\section{ARTICLE INFO}

Received: 13 September 2019

Accepted: 17 November 2019

Published: 30 November 2019

\section{KEYWORDS}

medical information system, combatants, PTSD, physical exercises, video analysis, rehabilitation, new knowledge.

\begin{abstract}
The paper discusses the features of building a system for managing the recovery of military personnel (SUOVS), including combatants who have been diagnosed with PTSD or there is a likelihood of its development. Based on the analysis, the requirement for the system is deduced - to influence all components of health (physical, psychological, social). The informational structure of health and the role of the state of the musculoskeletal system in it are considered. Exercise was chosen as a healing effect. It is shown that the optimal medium for creating video processing programs is the The Unified Algorithmic Platform (UAP). The use of UAP, technology of big data, machine learning will allow the SUOVS system to create new knowledge for rehabilitation.
\end{abstract}

Citation: Horbunov Oleh, Osadchyy Yevgen, Tereshchenko Vasyl. (2019) Some Issues of Creation the Conceptual Model Information System of Management for Recovery the Military Personnel. World Science. 11(51), Vol.1. doi: 10.31435/rsglobal_ws/30112019/6765

Copyright: (C) 2019 Horbunov Oleh, Osadchyy Yevgen, Tereshchenko Vasyl. This is an open-access article distributed under the terms of the Creative Commons Attribution License (CC BY). The use, distribution or reproduction in other forums is permitted, provided the original author(s) or licensor are credited and that the original publication in this journal is cited, in accordance with accepted academic practice. No use, distribution or reproduction is permitted which does not comply with these terms.

Вступ. Розробка системи управління оздоровленням військовослужбовців (СУОВС), в тому числі військовослужбовців, які побували в зоні бойових дій, як одна 3 найбільш актуальних завдань що стоїть перед суспільством в сьогодення і буде стояти в майбутнє час.

Актуальність викликана тим, що перебування на війні відноситься до тієї екстремальної ситуації, коли людина постійно перебуває у найсильнішому психо-емоційному стресі, долаючи його вольовими зусиллями. Обходиться усе це дуже високою ціною: майже, в усіх учасників бойових дій, неминуче, в тій чи іншій мірі, спостерігаються зміни у фізичному і психічному стані, виникають умови розвитку посттравматичного розладу (ПТСР).

Світова статистика показує, що кожен п'ятий учасник бойових дій навіть за відсутності яких-небудь фізичних ушкоджень страждає нервово-психічними розладами, а серед поранених і калік - кожен третій. Але це лише частина захворювань, які утворюються після екстремальних дій. Інші наслідки починають проявлятися через кілька місяців після повернення до нормальних умов життя. Це різні психосоматичні захворювання. За даними експертів військово-медичної академії, у учасників бойових дій (в порівнянні із здоровими людьми) в два-три рази вище вірогідність таких захворювань, як гіпертонічна хвороба, гастрит, виразкова хвороба шлунку і дванадцятипалої кишки. Загальний стан здоров'я характеризується слабкістю, запамороченням, зниженням 
працездатності, головними болями, болями в ділянці серця, сексуальними розладами, порушеннями сну, фобічними реакціями. Здоров'я військовослужбовців інвалідів доповнюється також проблемами, які пов'язані з отриманим пораненням і травмою [1-5].

Результати дослідження. Система винна мати справу 3 такими категоріями осіб: ветерани, учасники бойових дій в минулому; інваліди, в минулому учасники бойових дій; військовослужбовці, які прибули з зони бойових дій; військовослужбовці, які приходять службу поза зоною бойових дій. Таким чином, однією з вимог до системи СУОВС, є вимога сформувати вплив для всіх складових здоров'я: фізичного, психологічного, соціального.

Інформаційну структуру здоров'я в системі СУОВС представляємо як ієрархічно розгалужене дерево 3 п'ятьма рівнями. Кожен рівень, у свою чергу, містить різну кількість інформаційних моделей, що відображають його поточний стан [6].

Перший рівень структури здоров'я, утворює індивідуальне інтегральне здоров'я.

Другий рівень утворюють окремі сторони здоров'я - так звані статуси: фізичний, психічний і соціальний.

Третій рівень утворюють компоненти статусів здоров'я, кожна 3 яких має власну структуру i функцію. Компоненти фізичного здоров'я представленні: внутрішніми фізіологічними системами організму i керуючими системами організму. Компонентами психічного здоров'я виступають: інтелект, емоції і характер. Компонентами соціального здоров'я виступають: особистісно-середовищна і особистісно-моральнісна компоненти.

Четвертий рівень утворюють складові компоненти. Для компоненти внутрішньої фізіологічної системи організму - це окремі фізіологічної системи організму, наприклад, серцево-судинна система, система дихання, система крові, опорно-рухова система. Для керуючої системи організму - нервова система, імунна система і ендокринна система.

Складовими інтелектуальної компоненти виступають: властивості мислення, пам'яті, уваги та сприйняття. Складовими емоційної компоненти є суб'єктивні переживання індивіда - власне внутрішня (імпресивна складова) і зовнішня (експресивна складова), які можна визначити за мімікою, мовою, руховими актами і поведінкою людини и повинні аналізуватися системою.

Показниками складових компоненти характеру обрані якості особистості, що найбільше ніж інші відповідають за збереження та підтримку здоров'я: соціальна активність, вольова мобілізація, емоційне забарвлення діяльності, генерація поведінкових проявів. Як складові соціальної «особистісно-середовищной» компоненти прийняти: активність у соціальних мережах, адаптація до фізичних умов життя, адаптація особистості до умов трудової діяльності та навчання, адаптація до морально-етичних норм суспільства.

Особистісно-моральнісну компоненту, на наш погляд, утворюють таки п'ять «ключових» складових якостей соціально зрілої особистості: честь, совість, достоїнство, відповідальність, доброчинність. Ці параметри можуть використовуватися для мотивації пацієнта до самостійного виконання лікувальних вправ і завдань.

П'ятий рівень структури здоров'я формують окремі показники всіх складових здоров'я. Так, для серцево-судинної системи як складової - це: частота серцевих скорочень, систолічний артеріальний тиск, діастолічний артеріальний тиск, хвилинний обсяг серця та ін.

Особливістю розроблюваної системи СУЗВС є розгляд стану опорно-рухового апарату і окремих його параметрів, як невід'ємну характеристику фізичного здоров'я ВС, а також як найважливіший фактор оздоровлення організму в цілому і який надає позитивний вплив на окремі складові здоров'я: фізичне, психологічне і соціальне.

В якості ефективних методів оздоровлення і найбільш доступних для використання, як в різних спеціалізованих лікувальних установах, так i в самостійному використанні в повсякденному житі вибрані фізичні вправи, які належать до різних традицій і шкіл.

Для доказу доцільності i ефективності корекції стану ОРА були розроблені i впроваджені в практику протоколи досліджень обсягів руху різних частин тіла, дослідження постави і наявність міофасциальних дисфункцій, асиметричність руху та інші [7-9].

На підставі даних обстеження мультидисциплінарною командою лікарів (терапевта, невропатолога, психотерапевта, ортопеда, хірурга і інших фахівців), фізичних реабілітологів, нейрофізіологів та психологів сформувалася індивідуальна програма курсу реабілітації 3 використанням не медикаментозних методів лікування, проводився контроль за ії виконанням, та в випадку необхідності коригували іiі та проводили аналіз ефективності. 
Аналіз літератури і наші досліджувати показав позитивний вплив фізичних вправ на якість життя і здоров'я у військовослужбовців і ветеранів з ПТСР [10-13].

Функціональний стан пацієнтів оцінювали 3 використанням загальних обстежень фахівців і клінічних досліджень. Додатково проводився постуральний аналіз, м'язове тестування з оцінкою м'язового тонусу та наявністю м'язово-фасціальних дисфункцій, аналіз обсягу рухів, ЕЕГ- та ЕКГ- дослідження та аналіз диполів активності головного мозку 3 використанням програми LORETA і варіаційна пульсометрія під час тестування реакції вибору. Також проводились психологічне тестування пацієнтів: тест Малкова, тест Стилберга, тест Риффа, тест Люшера, тест шкала САН, тест Фельденкрайза, тест Руфье, та інші [14.15].

На підставі отриманого досвіду, робимо укладення, що для ефективної індивідуальноорієнтованої програми реабілітації, необхідно включати наступні фізичні вправи: усвідомлене дихання та рух, медитативні практики, розтяжка м'язів, спеціальні вправи для хребта, комплекс кінезіологічних вправ для покращення стану когнітивних функцій, кардіо-тренування, силові вправи, спеціальні медичні вправи за наявності травм та поранень з використанням апаратів трансформерів "Екзоскелетон" [14-16].

3 вище сказаного випливає, що для найбільш повного і всебічного відновлення здоров'я військовослужбовців, хто перебував в зоні бойових дій, необхідно використовувати велику кількість різноманітних фізичних вправ, які належать різним практикам (школам) тренування. Крім того, богато вправ, для досягнення позитивного ефекту, необхідно багаторазово повторювати протягом дня під контролем інструктора. На практиці, це вимагало б велику кількість високопрофесійного персоналу, що неможливо виконати в нашій дійсності.

Виконання, таким чином, індивідуально складеного курсу реабілітації можливо тільки при використанні засобів інформаційних технологій, а саме інформаційних систем управління здоров'ям яким є СУОВС.

Таким чином, перед СУОВС, стоїть одна з основних задач реабілітації ОДА, а саме, проводити оцінку і корекцію виконуваних фізичних вправ, проводити оцінку динаміки змін виконання тестових завдань, під час лікування.

СУОВС повинна здійснювати оцінку та аналіз: біомеханіки постави; рухи кінцівок тіла і голови, щодо тулуба і відносно один одного; дрібної моторики рук; рух очей; емоцій. Крім того, система повинна будувати 3D-модель тіла, в статиці і динаміці (акт дихання: вдих, видих). Оптимальним середовищем для створення програм обробки, аналізу відеозображень $є$ модель єдиного алгорітмічного середовища (МСАС).

МСАС використовує загальну структуру даних і набір спільних алгоритмічних інструментів та процедур для комп'ютерного моделювання та візуалізації результатів розв'язання широкого класу прикладних задач [17-19].

Система управління оздоровленням військовослужбовців є по своїй суті медичною інформаційною системою і ій притаманне основне поняття IT в біології та медицині як технологи отримання нового знання [6,20,21].

Таким чином, система управління оздоровленням, на підставі аналізу складності і організації отримання знань про стан здоров’я військовослужбовця (опорно-рухового апарату), повинна створювати нове знання, про проведення лікувально-реабілітаційних заходів, шляхом алгоритмізації свідомих дій лікаря, фіксації його логіко-евристичний міркувань, призначення індивідуального плану лікування або проведення заняття.

В цьому випадку, робота лікаря (мультидисциплінарної команди) об'єднується з СУОВС новими алгоритмами взаємодії, новими протоколами прийняття рішень, а ефективність лікування визначається взаємодією інтелектуальних можливостей лікаря і медичної інформаційної системи, причому, значну частину рутинної і інтелектуальної роботи приймає на себе система СУОВС.

Це визначає, таку вимогу до системи, а саме можливість зберігання великих обсягів інформації (технологія BIG DATA), можливістю отримувати нове знання з отриманих даних (технологія машинного навчання), частину рутинної і інтелектуальної роботи приймає на себе система СУОВС.

Висновки. Основні вимоги пред'являються до системи управління оздоровленням військовослужбовців, такі:

1. Система повинна створюватися з використанням трансформерні технології, тобто одні й ті ж алгоритми і програми можуть використовуватися для вирішення різних завдань лікування. 
2. Система повинна впливати на всі складові лікувального процесу: фізіологічна (впливати на тіло), соціальна (видавати інформацію лікарям, членам сім'í), особистісна (видавати інформацію пацієнтові).

3. Система повинна мати функції телереабілітації, мати можливість керувати відновленням ОРА на віддаленій відстані, підтримувати зв'язок з усіма соціальними складовими процесу.

4. Система повинна мати можливість зберігати великий обсяг даних про проходження лікування кожного пацієнта.

5. Система повинна дозволяти отримувати нові знання для побудови ефективних програм оздоровлення методами штучного інтелекту (методи машинного навчання).

6. Система повинна забезпечувати інформаційну безпеку, захист персональних даних пацієнта на всіх етапах реабілітації.

7. Система повинна мати можливість навчати пацієнта самостійної роботи з системою $\mathrm{i}$ давати можливість проводити лікувальні заняття з іншими.

8. Система повинна містити інтелектуальні трансформерні пристрої типу «Екзоскелетон», що наділяє людину, з обмеженим рухом, можливостями здорової людини.

Побудова медичної інформаційної системи оздоровлення військовослужбовців, їх опорнорухового апарату на основі даної концептуальної моделі дозволить вирішити сучасну актуальну задачу - задачу формування здорової нації, так як можна застосовувати до всіх верств населення.

Покладені в основу засоби і методи оздоровлення і профілактики, а саме різні фізичні практики, носять комплексний характер впливу на всі системи організму і $\epsilon$ найбільш доступними у використанні.

Єдина програмно-алгоритмічна середовища візуалізації та комп'ютерного моделювання та технологія машинного навчання, що лежить в основі системи СУОВС, робить ії сучасної та конкурентно здатної в області охорони здоров'я, здатної створювати нові знання для сучасної ефективної реабілітації.

\section{ЛIТЕРАТУРА}

1. Warshaw. M.G., et al. (1993). Quality of life and dissociation in anxiety disorder patients with histories of trauma or PTSD. Am J Psychiatry, 150, 1512-16

2. Zatzick D.F., et al. (1997). Posttraumatic stress disorder and functioning and quality of life outcomes in a nationally representative sample of male Vietnam veterans. Am J Psychiatry, 154:1690-95

3. Miller K.E., et al. (2002). The relative contribution of war experiences and exile-related strossors to levels of psychological distress among Bosnian refugees. J Trauma Stress, 15:377-87.

4. Wolfe. Schnurr P.P., Brown P.J., Furey J. (1994). Posttraumatic stress disorder and war-zone exposure as correlates of perceived health in female Vietnan war vetcrans. J Consult Clin Psychol, 62:1235-40

5. Stewart A.L., et al. (1994). Long-term functioning and well-being outcomes associated with physical activity and exercise in patients with chronic conditions in the Medicall Outcomes Stucy. J Clin Epidemiol, 47:7

6. Гриценко В.І., Котова А.Б., Вовк М.I, Кіфоренко С.І., Белов В.М. Інформаційні технології в біології та медицині. Наукова Думка. Київ.2007

7. Горбунов О.А., Попов А.А., Осадчий Е.А., Інформаційні трансформерні технології в лікувальнореабілітаційному процесі хворих 3 опорно-руховими порушеннями. Перший Всеукраїнський з'їзд «Медична та біологічна інформатика і кібернетика» 3 міжнародною участю. 23-26 червня 2010, Київ. С 74.

8. Горбунов О.А. Видеоанализ движений в реабилитационном осмотре неврологических больных. Матеріали щорічної науково-технічної школи-семінару «біологічна і медична інформатика та кібернетика. Київ. 2012,. С 18.

9. Мінцер О.П.,Попов А.О.,Анісімов А.В., Алеєв Л.С., Осадчий Є.О., Краснов В.В.,Івашківський О.І.,Барчина Ю.М. Формалізація медичних даних як перший етап створення інформаційних систем $\mathrm{i}$ архетипів при моніторингу хворих з ушкодженнями хребта і великих суглобів, що застосовують апарат "Екзоскелетон" //Методичні рекомендації /ДУ ІТ О АМН України. Київ. 2009,

10. Dimeo F., Bauer M., Varahram I., Proest G., Halter U. (2001). Benefits from aerobic cxercise in paticnts with major depression: a pilot study. Br J Sports Med, 35:114-7.

11. Dunn A.L., Trivedi M.H., O'Neal H.A. (2001). Physical activity dose-response effects on outcomes of depression and anxiety. Med Sci Sports Exerc, 33:S587-97.

12. Otter L. Currie J. (2004). A long time getting home: Vietnam Veterans' experiences in a community exercise rehabilitation programme. Disabil Rehabil, 26:27-34

13. Manger T.A., Motta R.W. (2005). The impact of an exercise program on posttraumatic stress disorder, anxiety, and depression. Int J Emerg Ment. Health, 7:49-57.

14. Zmazhenko O., Filimonova N., Makarchuk M., Zyma I., Horbunov O., Kalnysh V. The Influence of «Acoustic Peak» of theAudiograms on the Structure of the Neuronets of the Brain at Veterans of OOS With Traumatic 
Brain Injury During Testing Visual Working Memory. Lesya Ukrainka Eastern European National University Scientific Bulletin. Series: Biological Sciences. Human and Animal Physiology 2019, 3 (387),P.116-122.

15. Лисенко В.Ю., Анісімов А.В., Горбунов О.А., Кляцький Ю.В. Алгоритми фізичної реабілітації військовослужбовців з використанням практики усвідомлених рухів в санаторних умовах. Матеріали міжнародного конгресу з медичної і психологічної реабілітації. 30-31 жовтня 2017р. м.Київ. С.4-6.

16. Горбунов О.А., Осадчий Е.А. Трансформера інформаційна технологія вдосконалення рухової активності в нормі та патології - комплекс ПТАР. http://dsr.univ.kiev.ua/upload/iblock/545/5.20.-transformernainformatsiyna-tekhnologiya-vdoskonalennya-rukhovoyi-aktyvnosti-v-normi-ta-patologiyi-_-kompleks-ptar.pdf

17. Терещенко В. М. Побудова єдиного алгоритмічного середовища для розв'язування комплексу задач обчислювальної геометрії: дис. ... д-ра фіз.-мат. наук : 01.05.01. Нац. ун-т ім. Тараса Шевченка. Київ, 2016. 312 с.

18. Tereshchenko V. N., Anisimov A. V. Recursion and parallel algorithms in geometric modeling problems. Cybernetics and Systems Analysis. 2010. Vol. 46, No. 2. P. 173-184.

19. Tereshchenko V. N., Budjak I., Fisunenko A. The Unified Algorithmic Platform for Solving Complex Problems of Computational Geometry, Parallel Computing Technologies. 2013. Vol. 7979. P. 424-429.

20. Горбунов О.А., Осадчий Е.А.,Терещенко В.М,.., Кляцький Ю.В, Лысенко В.Ю. Інформаційна система фізичної реабілітації «ПТАР-ІТ». 1 Всеукраїнська науково-технічна конференція «Комп'ютерні технології: інновації, проблеми, рішення», 19-20 жовтня 2018 р. м. Житомир. https://conf.ztu.edu.ua/wp-content/uploads/2019/02/169-1.pdf.

21. Завгородний В.А., Горбунов О.А., Попов А.А., Осадчий Е.А. Слово о принципах медицинских информационных систем и медицинских информационных технологиях в интернете. Перший Всеукраїнський з'їзд «Медична та біологічна інформатика і кібернетика» 3 міжнародною участю. 23-26 червня 2010, Київ. С 33. 